Power centres and marginal landscapes: Tracking pre- and post-conquest (late Iron Age and Medieval) land-use in the Cēsis Castle hinterland, Central Latvia

Article

Accepted Version

Brown, A. ORCID: https://orcid.org/0000-0001-6943-645X and Pluskowski, A. ORCID: https://orcid.org/0000-0002-4494-7664 (2021) Power centres and marginal landscapes: Tracking preand post-conquest (late Iron Age and Medieval) land-use in the Cèsis Castle hinterland, Central Latvia. Environmental Archaeology: The Journal of Human Palaeoecology, 26 (4). pp. 471-486. ISSN 1461-4103 doi:

https://doi.org/10.1080/14614103.2020.1790082 Available at https://centaur.reading.ac.uk/92144/

It is advisable to refer to the publisher's version if you intend to cite from the work. See Guidance on citing.

Published version at: http://dx.doi.org/10.1080/14614103.2020.1790082

To link to this article DOI: http://dx.doi.org/10.1080/14614103.2020.1790082

Publisher: Taylor \& Francis

All outputs in CentAUR are protected by Intellectual Property Rights law, including copyright law. Copyright and IPR is retained by the creators or other copyright holders. Terms and conditions for use of this material are defined in 
the End User Agreement.

www.reading.ac.uk/centaur

\section{CentAUR}

Central Archive at the University of Reading

Reading's research outputs online 


\title{
Power centres and marginal landscapes: tracking pre- and post- conquest (late Iron Age and medieval) land-use in the Cēsis castle hinterland, central Latvia
}

\author{
Alex Brown ${ }^{1,2 *}$, Aleks Pluskowski ${ }^{2}$ \\ 1 - Wessex Archaeology, Portway House, Old Sarum Park, Salisbury, SP4 6ED, UK \\ (corresponding author) \\ 2 - Department of Archaeology, University of Reading, Whiteknights, Reading, RG6 6AB, \\ UK
}

\begin{abstract}
During the late Iron Age, the eastern Baltic was inhabited by Finno-Ugric and Baltic speaking societies whose territories were conquered in the $13^{\text {th }}$ century as a result of the crusades. This paper examines the degree to which indigenous landscapes were transformed as a result of the crusades, and the evidence for maintenance of indigenous land-use practices. Vegetation and land-use history are reconstructed using palynological data from Cēsis castle and its hinterland. Comparison is made with selected palynological, archaeological and documentary data across Livonia (Latvia and Estonia) and contrasted with the greater impact of the crusades in nearby Prussia. Despite the emergence of key power centres in the medieval period, including towns and castles such as Cēsis, many parts of the rural landscape remained largely unchanged by the crusades, particularly in those more marginal landscapes studied in this paper. Lower intensity land-use can be linked to poor agricultural soils but also reflect the limited colonization of rural landscapes beyond the major towns and castles. Indigenous societies and practices survived to a greater degree, with later agricultural intensification in the $14^{\text {th }}$ century reflecting the increasing political stability, grown of urban centres, establishment of serfdom and the development of the manorial system.
\end{abstract}

Keywords: Palaeoecology; land-use, crusades. Iron Age, medieval period, Livonia

1. Introduction 
During the late Iron Age, the lands of the eastern Baltic, roughly equating with modernday Latvia and Estonia, were inhabited by Finno-Ugric and Baltic speaking societies. These societies, centred on strongholds, have been linked to historically documented tribal groupings and territories that begin to appear in the cultural record during the course of the Iron Age (Šnē 2005, 2006), and that in parts of the eastern Baltic saw significant demographic and economic expansion (Kihno and Valk 1999). However, these societies and their territories were utterly transformed in the early $13^{\text {th }}$ century as a result of the crusades, starting in what is today Latvia in 1209 and lasting until 1290. The crusades in the eastern Baltic were followed in 1230-1280 by successful crusades in Prussia (present-day north-east Poland, Russian Kaliningrad and north-western Lithuania) that together resulted in the subjugation of pagan tribal lands and their replacement with a theocratic state run by the military orders and their episcopal allies (Figure 1). The conquered territories in the eastern Baltic, referred to as Livonia (derived from the German 'Livland', itself derived from the indigenous Livs who inhabited the Lower Daugava region), were reorganised into a series of hierarchical administrative territories run by the Livonian branch of the Teutonic Order (and their predecessors in the region the Sword Brothers) and individual bishops. The conquest was accompanied by the foundation of new urban centres and the construction of heavily fortified castles, followed by the development of trading networks and increasing exploitation of natural resources.

There has been an increasing interest in investigating the impact of cultural processes in transforming the landscapes of north-eastern Europe, traditionally understood through archaeological and historical data (Christiansen 1997; Urban 2003). However, there is a growing body of palaeoenvironmental data from the region covering the late Iron Age and medieval periods that demonstrates the high degree of chronological and spatial variation in patterns of vegetation change and land-use (e.g. Veski et al 2005; Latałowa et al 2009; Lamentowicz et al 2008; Noryśkiewicz 2013; Szal et al 2014, 2016; Wacnik et al 2014, 2016; Poska et al 2014; Pędziszewska and Latałowa, 2015; Brown et al 2015, 2019; Stivrins et al 2015, 2016), reflecting the complex and divergent patterns of pre- and post-conquest settlement and society across the new theocratic state. Livonia differs critically from Prussia in seeing lower levels of colonization following the crusades, with migrants restricted largely to towns and castles, and with a greater survival of indigenous populations. 
This paper examines the ecological signals of vegetation change and land-use over the late Iron Age and medieval periods (c. $10^{\text {th }}-16^{\text {th }}$ centuries), and in particular, the evidence for the impact of the crusades, through a comparison of palynological data from five pollen sequences from what became one of the key power centres in the medieval eastern Baltic; one from the moat at Cēsis castle (formerly German Wenden) and four from its territory or commandery. From 1413, the castle became increasingly used as the residence of the Livonian Master, eventually resulting in his permanent relocation from the Order's regional headquarters in Riga. The castle was located adjacent to the site of the former Iron Age hillfort and central place of the indigenous Vends. However, even today large parts of the surrounding landscape retain significant woodland with only sparse settlement and limited agriculture. The pollen studies from across this landscape present an interesting case-study examining the ecological impact of cultural change on the marginal landscapes of a key power centre, providing a comparison to existing published palynological data across the region and from a range of landscape and cultural settings (Brown et al 2019, Stivrins et al 2015, 2016, 2019).

To what extent were indigenous landscapes transformed as a result of the crusades and what is the evidence for the maintenance of indigenous land-use practices? How does the environmental profile from an apparently marginal landscape compare with palaeoenvironmental data from varied landscape contexts across Livonia and Prussia (e.g. close to castles and urban centres, sparsely and intensively settled areas), and what does this suggest about the interplay of factors involved in shaping, changing and/or maintaining the landscape?

\section{Study Area}

\subsection{Archaeology and history of the Cēsis and Livonia}

Cēsis is situated in present day north-eastern Latvia, located within the Gauja Valley within the northern part of the Central Vidzeme Upland (fig. 1). Modern names for places and territories are used throughout this article, with the first use followed by its equivalent in brackets. During the Iron Age the landscape was divided between a series of tribal territories. These groups have been assigned geographical territories based on associated distinctive material cultural, although directly correlating material culture and ethnicity is problematic. 
During the Iron Age, an indigenous group called the Vends occupied a hillfort (Riekstu hillfort) located adjacent to where the medieval castle would be built. The Vends appear to have been part of a north-eastward migration of Livs from Curonia (present-day western Latvia) in the $10^{\text {th }}$ century. The hillfort at Riekstu is located within a borderland between the Livs and Latgalians, a defined group in eastern Latvia that emerges from the $7^{\text {th }}$ century (Šnē 2005, 2006; Apala and Apals 2014, 116-117).

Late Iron Age settlement patterns have been interpreted in terms of hierarchical power, with hillforts at the top. The hillfort at Riekstu Hill is the only indigenous central place within this region, although other important settlements have been investigated within the wider landscape. These include the important fortified lake settlement at Āraiši (former German Arrash, ca. 8km south-east of Cēsis), occupied from the $9^{\text {th }}$ to mid-10 ${ }^{\text {th }}$ century (Apals 2012, Meadows and Zunde 2014), and later the site of a medieval castle founded in the $14^{\text {th }}$ century.

During the course of the $13^{\text {th }}$ century crusading armies conquered the eastern Baltic with the aim of converting indigenous pagan communities, protecting existing Christian converts and acquiring new territories. The Livonian Crusade began with the conquest of the Livs and Latgalians (1209-1227) (eastern Latvia) by the armies of the Bishops and Order of the Livonian Brothers of the Sword, and later, following by partially successful crusades in western Latvia (1219-1290) resulting in the subjugation of Curonia and northern Semigalia. Following their defeat by the Samogitians in 1236, the Sword Brothers were merged into the Teutonic Order.

In 1212, the Sword Brothers established a base at Cēsis on the site of the Riekstu hillfort. Occupation of the hillfort overlaps with the initial phases of construction of the adjacent stone castle. The construction of the castle was accompanied by the development of the adjacent town that received its charter in the $A D$ 1224. The castle was significantly expanded in the latter half of the $14^{\text {th }}$ century, representing an important centre for controlling the route linking Riga with the central territories of the Order in Livonia. The castle was increasingly used as the residence of the Livonian Masters from the early $15^{\text {th }}$ century and would become one of the most important centres of power in the eastern Baltic during the final phases of the Orders rule in Livonia during the $15^{\text {th }}$ and $16^{\text {th }}$ centuries.

The territory of Wenden adopted the River Gauja as a border and included a series of several smaller districts governed by advocates, based in the castles at Valmiera (Wolmar), Trikāta (Trikaten), Burtnieki (Burtneck) and Ergeme (Ermes), with the castle at nearby Āraiši (Arrasch) also subservient to Wenden. Data on the surrounding settlement is provided by a 
series of land audits, although dating only from the late $16^{\text {th }}$ century. These settlements will have been largely occupied by the local native population, with migrants communities limited to Wended castle and town. A 1601 Swedish land audit indicates that Cēsis castle had at least 95 farmsteads in 4 parishes and Āraiši with 116 farmsteads in 6 parishes, with a further 122 listed between the two castles, (Svabe 1933, 489). An earlier Polish land audit from 1582 documents listing 290 settlements in these 10 parishes (Ose 2011). However, not all these settlements were occupied; for example, only 10 of the 30 settlements in Gaidan parish are listed as occupied in the 1582 audit, no doubt a consequence of the ravages of the Livonia War (1558-1583).

The power of the Teutonic Order in Livonia gradually waned into the $16^{\text {th }}$ century, and the defeat of the Order by Muscovite forces in 1560 (part of the Livonian War) led to the Order seeking protection from Poland under King Sigusmund II. Following the secularization of the Order's Livonian branch in 1561, and conversion to the Lutheran faith, the territory became part of the Duchy of Livonia and Cēsis was garrisoned by Polish troops. However, large parts of the Duchy of Livonia later came under Swedish rule from 1621 during the Swedish-Polish wars, almost a century (1710) later falling under Russian rule following the Great Northern War between Sweden and Tsarist Russia.

\subsection{Biogeography and climate of central Latvia}

Latvia belongs biogeographically to the hemiboreal vegetation zone, characterised by mixed boreal coniferous and deciduous (boreo-nemoral) forests dominated by Pinus sylvestris, Picea abies, Betula and Alnus glutinosa, Alnus incana, along with smaller quantities of broadleaved trees including Fraxinus, Ulmus, Tilia, Quercus and Corylus avellana type. Today forests form approximately $55 \%$ of the land-area of Latvia (Forest Europe, UNECE and FAO 2011), with a lesser component covered by agricultural land (c. 32\%), with peatlands forming a $10 \%$ of the total land-area (Kalnina et al 2015). The relief of the eastern Baltic has been shaped primarily during the last glaciation and deglaciation, characterised by largely low-relief averaging no greater than $100 \mathrm{~m}$ a.s.l, with the highest points at c. $312 \mathrm{~m}$ a.s.l in the Vidzeme Uplands, north-east Latvia (Zelčs and Markots 2004). The climate is transitional with mean January and July temperatures varying between $-3^{\circ} \mathrm{C}--8^{\circ} \mathrm{C}$ and $+16-+18$ (Draveniece 2009) ). 


\section{Pollen sampling sites}

Five sediment sequences were selected for palynological analysis, three from bogs, one from a small herbaceous fen basin infill, and from sediments infilling the moat at Cēsis castle (fig. 1), forming part of a wider program of pollen analysis from sites across the south-eastern Baltic region, undertaken as part of the ERC funded Ecology of Crusading Project (2010-2014, FP7/2007-2013; grant no. 263735; Pluskowski 2019a, 2019b). The aim of the coring program was to target suitable sites representative of the likely range of landscape settings and patterns of land-use. The samples from the four off-site locations are reflective of the more marginal habitats existing within the hinterland of Cēsis. The data builds upon recently published data from Lake Āraišu ( $8 \mathrm{~km}$ south of Cēsis castle) associated with the site of an Iron Age lake settlement and medieval castle (Stivrins et al 2015), and Lake Trikatas, located adjacent to the medieval castle and village of Trikāta (former German Trikaten) (Stivrins et al 2016). All sites are located within the medieval territory of Cēsis castle.

\subsection{Blusu mire $\left(57^{\circ} 17^{\prime} 28^{\prime \prime} \mathrm{N}, 25^{\circ} 17^{\prime} 20.1^{\prime \prime} \mathrm{E}\right)$}

Medium sized bog (c. 45 hectares) located on the present south-eastern edge of Cēsis, $c$. $2.2 \mathrm{~km}$ from Cēsis castle. The bog is chiefly covered in Pinus, Betula and Picea woodland, especially along the margins. The centre of the bog is dominated by dwarf shrubs and bryophytes dominated by Sphagnum species. Coring within the bog indicates a relatively shallow depth of peat to a maximum depth of $1.5 \mathrm{~m}$, but typically no more than $0.75 \mathrm{~m}$. The core was taken from the greatest depth of deposits within the central area of the current bog, comprising moss (Sphagnum) peats $(0.10-1.06 \mathrm{~m})$ overlying structureless organic matter $(1.06-1.50 \mathrm{~m})$. The peat overlies silts, suggesting a former now infilled lake. Pollen was focused on the top $0.72 \mathrm{~m}$ of the core covering the last 1500 years; the peat at $1.4 \mathrm{~m}$ dated to $4878 \pm 33$ BP (GU-29816, 3710-3540 cal. BC).

\subsection{Nineris mire $\left(57^{\circ} 20^{\prime} 10.4^{\prime \prime} \mathrm{N}, 25^{\circ} 17^{\prime} 16.5^{\prime \prime} \mathrm{E}\right)$}

Small bog (c. 30 hectares) located adjacent to Lake Nineris and extending a further $800 \mathrm{~m}$ to the west. The bog comprises a sequence of ombrotrophic peats several metres deep. The bog surface is currently covered with young pine trees and a surface layer of dwarf shrubs, surrounded on the dry ground by mature Pinus plantation woodland. The top $2.5 \mathrm{~m}$ was 
sampled, comprising a Sphagnum-dominated moss peat, with palynological analysis undertaken to $2.18 \mathrm{~m}$ on sediments dating from the fourth century AD.

\subsection{Blaṇku mire $\left(57^{\circ} 23^{\prime} 12.4^{\prime \prime} \mathrm{N}, 25^{\circ} 18^{\prime} 05.1^{\prime \prime} \mathrm{E}\right)$}

Large bog (c. 300 hectares) $8 \mathrm{~km}$ north of Cēsis castle. The bog is largely open, dominated by dwarf shrubs and bryophytes with a sparse cover of young Pinus; the margins of the bog are surrounded by Pinus-dominated woodland. Coring across the bog indicates a shallow depth of moss peat to a maximum depth of 2.25 m overlying lacustrine silts. The peat was sampled to a depth of $2 \mathrm{~m}, c .150 \mathrm{~m}$ from the western edge of the bog. Analysis focused on the top $1.1 \mathrm{~m}$ covering the last 1500 years, comprising a well humified Sphagnum moss peat. The peat at $1.65 \mathrm{~m}$ dated to $2575 \pm 29 \mathrm{BP}$ (GU-29811, 810-570 cal. BC).

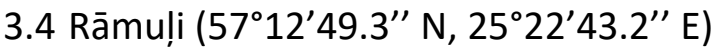

Small (4 hectares) basin infill $14 \mathrm{~km}$ ESE of Cēsis, located within the edge of pinedominated woodland adjacent to agricultural fields $1 \mathrm{~km}$ from the settlement of the same name. The deposits comprise a sequence of structureless herbaceous peats to a depth of 2.35 $\mathrm{m}$; only the top $1.75 \mathrm{~m}$ was sampled, with analysis undertaken on the top $0.5 \mathrm{~m}$, covering the last 1000 years.

\subsection{Cēsis castle moat $\left(57^{\circ} 18^{\prime} 46.7^{\prime \prime} \mathrm{N}, 25^{\circ} 16^{\prime} 14.3^{\prime \prime} \mathrm{E}\right)$}

Coring and excavations revealed a deep sequence of waterlogged sediment extending to a depth of c. $4 \mathrm{~m}$ within the moat fronting the southern range of the castle. Pollen samples were taken from 0.8-2.34 m, avoiding disturbed sediments at the top and overlying a timber drain at c. $2.5 \mathrm{~m}$, dendrochronologically dated to AD 1374/5. The sediments underneath the timber drain are both archaeologically and geochemically sterile and were not sampled; these sediments, homogenous in character, most likely accumulated rapidly after construction, eroding into the moat before the banks stabilised with vegetation.

\section{Materials and methods}

\subsection{Sampling}


Half metre cores were taken using a $5 \mathrm{~cm}$ diameter Russian auger, starting at the surface, with duplicate cores taken to cover the overlap. Cores were wrapped in cling film and foil, placed in plastic guttering and refrigerated prior to sampling.

\subsection{Pollen analysis}

Samples for pollen analysis were taken at intervals varying between 0.5 to $4 \mathrm{~cm}$, focusing on sediment of Iron Age, medieval and later date. Samples were prepared following standard laboratory techniques (Moore et al 1991) and mounted in glycerol jelly stained with safranin. A minimum of 500 pollen grains of terrestrial species were counted for each level. Pollen percentages are calculated based on terrestrial plants. Fern spores, aquatics and Sphagnum are calculated as a percentage of terrestrial pollen plus the sum of the component taxa within the respective category. Identification of cereal pollen followed the criteria of Andersen (1979). Identification of indeterminable grains was recorded according to Cushing (1967). The pollen diagram was produced using Tilia version 1.7.16 program (Grimm, 2011). Pollen zones are based on the principal archaeological periods rather than local pollen assemblage zones.

\subsection{Radiocarbon dating and chronological modelling}

A total of 29 AMS ${ }^{14} \mathrm{C}$ radiocarbon dates were obtained from SUERC (Scottish Universities Environmental Research Centre), nine from Blusu mire and, eight from Blanku mire and Nineris mire and three from Rāmuḷi (Table 1). Due to the absence of terrestrial plant macrofossils, radiocarbon dates were derived on bulk peat, taking care to identify any potential issues of contamination with old or young carbon.

Calibrated age ranges were calculated using OxCal 4.1 (Bronk Ramsey, 2009) using the IntCal13 calibration dataset (Reimer et al 2013) and modelled using the Bacon Bayesian statistical program (Blaauw and Christen 2011), using default settings for calculation of prior information (e.g. accumulation rates) (fig. 3).

A single dendrochronological data was produced on the remains of a spruce timber drain revealed in the base of southern moat of Cēsis castle

\section{Results}

\subsection{Chronology}


Reliable chronologies are a fundamental component of palaeoecological investigations. Although terrestrial plant macrofossils are considered the most reliable material for radiocarbon dating, samples of bulk peat from bogs are considered reliable material for dating (Nilsson et al 2001; Blaauw et al 2004). The peat deposits reflect treeless habitats, although some herbaceous plants growing in fens, such as sedges, have roots systems which can penetrate own $2 \mathrm{~m}$, with the potential to introduce young carbon unless removed (Valrianta et al 2014). However, no roots or evidence for rotting by either trees or herbaceous plants was recorded during the sampling of the cores. The radiocarbon dates for all sequences show a strong linear progression (fig. 3) and contamination of peat by young or old carbon is considered unlikely.

\subsection{Blusu mire (AD $500-1800)$ (fig. 3)}

During the middle and late Iron Age the vegetation is dominated by woodland comprising Betula (20-30\%), Picea (15-20\%+), Pinus sylvestris (25-35\%) and Alnus (10-15\%), with smaller quantities of other arboreal taxa including Corylus avellana type (<5\%), Quercus, Ulmus, Tilia and Carpinus betulus ( $\leq 1 \%)$. Alnus, Betula and Pinus sylvestris are likely to have formed the primary component of woodland growing within bog, with a ground flora including dwarf shrubs (Calluna vulgaris and Ericaceous plants) and bryophytes (largely Sphagnum). Occasional pollen grains of ruderal taxa (Artemisia type, Chenopodiaceae) may reflect the activity of wild grazers and browsers within the bog. However, microscopic charcoal levels (ca. AD 550-700) may reflect small-scale slash and burn agriculture in the surrounding landscape not visible in the pollen record.

Significant vegetation change is not apparent until the early/mid-fourteenth century with the first appearance of Secale cereale and an increase in grasses and ruderal pollen (Rumex acetosa/acetosella type), intensifying during the fifteenth century and including cereal pollen grains of Avena-Triticum, Hordeum and very occasional Fagopyrum esculentum. Picea declines from 20-5\% from AD 1200-1400, with higher values for Pinus sylvestris of up to 40\% (AD 1250-1400) (30-40\%) declining sharply thereafter to 15\%. Dwarf shrubs (Calluna vulgaris, Ericaceae) and Sphagnum expand on the bog surface; the increase in Sphagnum (up to 60\%) occurs at the transition from largely herbaceous to moss peat, reflecting the development of ombrotrophic bog. The increase in Calluna vulgaris (10\%) likely reflects its growth on drier hummocks and ridges in the bog that often forms in-between wetter areas dominated by 
Sphagnum. Pollen of cultivated, disturbed and open ground flora generally increase in during the post medieval period, although declining values and lower palynological diversity are apparent during the $17^{\text {th }}$ century.

\subsection{Nineris mire (AD $400-1950)$ (fig. 4)}

Woodland predominates throughout the Iron Age. Pinus sylvestris values range between 35-65\%, with Betula declining from 40\% (AD 400) to <20\% (AD 600-700), remaining constant at $30 \%$ during the late Iron Age (AD 800-1200). Picea values increase from AD 600, up to 30\% ( $A D$ 650), decreasing from $20 \%$ to $<10 \%$ at ca. $A D$ 1050. Other arboreal taxa are present, particularly Alnus (ca. 10\%) along with small quantities of Corylus avellana-type $(<5 \%)$, Quercus, Ulmus, Tilia, Carpinus betulus ( $\leq 1 \%)$ and occasional Salix, Fraxinus excelsior, Fagus sylvatica and Acer. Small-scale agricultural activity is suggested during the Iron Age by occasional cereal pollen grains of Secale cereale, Avena-Triticum and Hordeum.

The proportions of arboreal pollen taxa remain relatively stable until the $14^{\text {th }}$ century when Picea declines ( $<10 \%)$, followed by Betula to $<20 \%$ by $A D 1500$. There is however a gradual increase in Alnus (5-15\%) over the course of the medieval period, accompanied by higher values for Ericaceae (up to $5 \%$ ) and Calluna vulgaris (max 10\%). Secale cereale is sporadically present through the medieval period, with occasional Avena-Triticum and Hordeum and a single pollen grain of Fagopyrum esculentum recorded during the $15^{\text {th }}$ century. Ruderal (Rumex acetosa/acetosella-type, Chenopodiaceae) taxa also increase from the $14^{\text {th }}$ century along with pollen of Poaceae. The post-medieval is characterised by an expansion in Ericaceae (5\%) and Sphagnum (40-60\%) on the bog surface, with Alnus increasing (15-20\%), most likely growing on moist soils. During the post-medieval, the period of Polish/Swedish rule sees a decline in evidence for agricultural activity although values for cereal and ruderal pollen increase again into the eighteenth century. Woodland however remains dominant, with Pinus sylvestris increasing in value from 20-60\% (AD 1800) but with a decline in Picea (5\%), Alnus (5\%).

\subsection{Blaṇḳu mire (800 BC - AD 2000) (fig. 5)}

Woodland dominates the majority of the sequence, largely comprising Pinus sylvestris, Betula and Picea. During the Bronze Age arboreal pollen is initially dominated by Picea (30\%), declining sharply to $<10 \%$ (700 BC), with an increase in Betula (20-45\%) and Pinus sylvestris 
(10-30\%) by the end of the Bronze Age. Alnus (10\%) and Corylus avellana type (5-7\%) occur in smaller quantities along with Tilia, Quercus ( $\leq 4 \%)$, Ulmus and Carpinus betulus $(<1 \%)$ and a range of other arboreal taxa.

During the early Iron Age Betula declines to $20 \%$ at 500 BC, with an increase in Picea to $35 \%$ at $100 \mathrm{BC}$, declining to $<10 \%$ by $A D 100$. Pinus sy/vestris values gradually increase during the early Iron Age from ca. $20-40 \%$. Alnus and Corylus maintain broadly stable values whilst both Quercus and Tilia decline ( $<1 \%)$. Betula increases during the middle Iron Age to $40 \%$, declining to $30 \%$ during the late Iron Age, with Pinus sylvestris constant at ca. $30 \%$ and Picea increasing to $15 \%$ at ca. $A D 400$ and $A D 600$ and to $20 \%$ by $A D 900$. Picea declines sharply however to $10 \%$ from $A D 1100$. The surface ground vegetation of the bog is represented by Calluna vulgaris and spores of Sphagnum (10-60\%) and occasional pollen of a range of herbaceous taxa (e.g. Rosaceae, Filipendula, Potentilla).

There is minimal evidence for human activity during the Iron Age, with only a single windpollinated Secale cereale pollen grain from the early $12^{\text {th }}$ century. This single grain could have been transported over a long distance within the pollen source area of the bog and is insufficient on its own to suggest localised agriculture.. Pollen of cultivated and ruderal species only increase towards AD 1300, with wind-pollinated Secale cereale most prominent along with increasing frequencies of Rumex acetosa-type, Artemisia type and Poaceae, suggesting areas of meadow and pastureland. Although woodland still dominates, Picea forms a minor component (<10\%) of a canopy largely comprising Pinus sylvestris (30-40\%) and Betula (20-25\%)

The evidence for increasing agricultural activity during the medieval period, from $A D$ 1300 , contrasts with the latter half of the $16^{\text {th }}$ and $17^{\text {th }}$ century during the period of PolishSwedish rule. Lower values for cereal and ruderal pollen suggest some regression in arable and pastoral land-use at this time, accompanied by an increase in arboreal pollen. This is followed by an increase in Secale cereale and Rumex acetosa/acetosella type during the $18^{\text {th }}$ century.

5.5 Rāmuḷi (AD 1000 - 1700) (fig. 6)

Woodland dominates the sequence, largely comprising Picea, Pinus sylvestris, Betula and Alnus. During the Iron Age arboreal pollen largely comprises Picea (ca. 25-40\%) and Pinus Sylvestris (ca. 15-33\%), but with a shift during the mid-14 th $15^{\text {th }}$ century with increasing 
Pinus sylvestris (ca. 45\%) and a significant decline in Picea (ca. $10 \%$ by the end of the $15^{\text {th }}$ century). Betula values increases, particularly from the $16^{\text {th }}$ century (ca. $30-35 \%$ ).

There is little evidence for human activity in the pollen sequence prior to the 13 th $/ 14^{\text {th }}$ century with an increase in Poaceae and intermittent grains of Secale cereale, Avena-Triticum and Hordeum, occasional Centaurea cyanus and ruderal taxa are associated with a decline in arboreal pollen.

\subsection{Cēsis castle moat (fig. 7)}

Interpretation of the pollen sequence rests on the assumption (in the absence of evidence that the moat was ever cleaned out) that the sequence reflects the gradual accumulation of sediment following the construction of a timber drain, dendrochronologically dated $\mathrm{c}$. 1374/5. The deposits contain significantly less arboreal pollen than off-site sequences (ca. 3040\%), largely comprising Pinus sylvestris (ca. $20 \%$ ) and Betula (>10\%). There are significant quantities of cultivated taxa (10-20\%), including Avena-Triticum, Hordeum, Secale cereale and Fagopyrum esculentum, accompanied by pollen of field weeds such as Centaurea cyanus, Scleranthus (knawels) and Agrostemma githago (common corn cockle). Ruderal taxa include Rumex acetosa, Chenopodiaceae, Brassicaceae (mustards/cabbages) and Artemisia.

\section{Discussion}

\subsection{The Iron Age}

Pollen analysis from sites around Cēsis showed a landscape dominated by mixed boreal coniferous and deciduous woodlands throughout the late Iron Age and medieval periods, chiefly comprising pine, spruce and birch. Occasional pollen grains of cereal and ruderal taxa point towards some small-scale agricultural land-use within the wider Cēsis landscape during the late Iron Age. The generally low level of human activity in the pollen sequences is perhaps not unsurprising. Many are located in isolated settings peripheral to areas of human settlement, or, as in the case of Nineris, Blusu and Blanku mires, are located in areas with largely sandy soils (European Soils Portal) of marginal to poor agricultural potential. Predominantly sandy soils are distributed to the north, north-east and north-west of Cēsis and today these areas retain a heavy woodland cover. However, heavy boulder clay soils more suited to intensive cultivation are distributed to the south-east of Cèsis where 
paleoenvironmental analysis suggests a mosaic vegetation landscape in places during the late Iron Age.

Pollen and fungal spore analysis from Lake Āriašu, $6.5 \mathrm{~km}$ south of Cēsis, revealed significant evidence for human activity during the late Iron Age (Stivrins et al 2015) associated with a lake settlement occupied from c. AD 780 to the early/mid-eleventh century (Apals 2002; Meadows and Zunde 2014; Punning et al 1968). Although the first appearance of cereals and a gradual opening up of the woodland environment occurred towards the end of the middle Iron Age (AD 400-800), land-use was most intensive between the mid-eighth to mid-eleventh centuries, resulting in a semi-open landscape surrounding the lake comprising a mosaic of cultivated land, meadows and pasture. Despite the abandonment of the lake settlement by the mid-eleventh century, intensive agricultural land-use continued in the surrounding landscape for the remainder of the late Iron Age.

By comparison, pollen studies from Lake Trikāta, 37 km north-north-west of Cēsis, suggest a heavily wooded landscape with minor agricultural land-use during the late Iron Age (figs. 2 - 6; Stivrins et al 2016), despite the reference in Henry's Chronicle of Livonia (IV, 12) in 1208 to Trikaten as the location of one of two strongholds ruled over by the local Lettish chieftain.

Available radiocarbon dated pollen studies from southern Livonia support the picture of a heavily wooded landscape across much of the landscape (see Brown and Pluskowski 2014 for a broader discussion of the available pollen data from Livonia), at least beyond the immediate locales of settlements, with several sequences from peripheral locations, including Rozu and Zilais mires, showing little or no evidence for human activity during either the Iron Age or medieval periods (Kalnina et al 2014; Ozola 2013). Small increases in pasture and

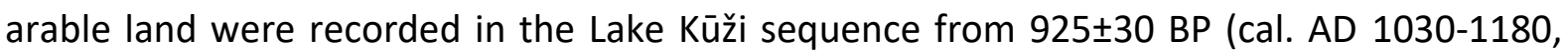
Kangur et al 2009), from c. 1000 at Zosna peatland (Ozola 2013), with a continuous Cerealia pollen curve from c. $500 \mathrm{BC}$ and intermittent rye pollen from the tenth century at Lake Kurjanovas (Heikkilä and Seppä 2010). The sparse palynological evidence from Latvia for intensifying land-use during the late Iron Age, apart from around central spaces such as Āraiši (Stivrins et al 2015) contrasts with the archaeological and historical record from the eastern Baltic that demonstrates this was a period of demographic and economic expansion (Khino and Valk 1999) and reflects the peripheral location of many pollen sequences away from archaeological sites. and 
The settlement record for Estonia shows an increase in new sites during the eleventh to thirteenth centuries (Laul and Valk 2007), particularly focusing in the north-west and on the island of Saaremaa. The archaeological material points towards a rapid development from the $10^{\text {th }}$ century with the Danish book of land taxation (Liber Census Daniae) listing 3000 farmsteads on Saaremaa by the AD1300 (Ligi 1992), and several pollen studies showing increasing human impact on the landscape during the Iron Age (Poska and Saarse 2002; Hansson et al 1996). In southern Estonia these concentrate mainly in the south-east where palaeoenvironmental data suggests increasing landscape openness in places during the late Iron Age (Poska et al 2008, 2014; Niinemets and Saarse 2009; Kihno and Valk 1999). Southwestern Estonia by comparison was more sparsely populated, largely as a consequence of the many large bogs and vast tracts of woodland covering the landscape.

\subsection{The medieval period}

The palynological evidence from the Cēsis commandery does not suggest a significant change in the intensity of land-use at the beginning of the medieval period. Sustained increases in cereal and ruderal pollen are only apparent from the late thirteenth/early fourteenth century at Blanku mire, from the late fourteenth/early fifteenth century at Blusu mire and Rāmuli, and from the early sixteenth century at Nineris mire. This pattern is reflected in many radiocarbon dated pollen sequences across southern Livonia that show only small increases in pollen indicative of pasture/meadow and arable land during the medieval period; at Eipurs bog from a level dated $689 \pm 50$ BP (cal. AD 1230-1400), Dzelve-Kronis bog after 757士55 BP (cal. AD 1170-1380, Kuške et al 2010) with intermittent increases in rye pollen at Bazi Mire from 742 \pm 90 BP (cal. AD 1045-1410, Pakalne and Kalnina 2005). Pollen from extensive mires located in peripheral areas of otherwise low agricultural potential is unlikely to produce evidence for significant human impact on the environment, providing potentially false-negative evidence for human activity. However, the consistent although low values for rye and other cereals, and intermittent weeds, at least point to an increase in arable fields and pastoral land in the wider landscape surrounding Cēsis from the late thirteenth century. Although wind-pollinated rye typically occurs in larger quantities in pollen sequences than other self-pollinated cereals, it may have been preferred in areas with nutrient poor sandy soils because of the ability of its fibrous root system to exploit water to a greater depth than other cereals (Vaughan and Geissler 1997). 
The reduction in arboreal pollen in sequences surrounding Cēsis, particularly spruce, also points towards increasing human impact within the landscape during the medieval period. Declining spruce values have been linked in parts of Sweden and Finland to expanding agrarian land-use (Segerström 1990) including canopy thinning to create meadows and forest pastures (Segerström and Emanuelsson 2002); such a strategy may have been employed around Cēsis in areas of poorer arable potential.

Prior to the fourteenth century, the picture from pollen sequences therefore appears to be one of continuity or even decline in the intensity of agricultural activity during the thirteenth century. However, at Lake Trikāta major changes in vegetation and intensification in land-use are apparent in the pollen data following the crusades (Stivrins et al 2016). Declining arboreal pollen is accompanied by an increasing range and frequency of cultivated and ruderal taxa from the mid-thirteenth century, suggesting significant clearing of the surrounding woodland and the development of a mosaic landscape of arable, pastoral and disturbed ground. The mosaic nature of the landscape suggested by the pollen is further emphasised by documentary sources listing a range of different land-uses. Descriptions of a boundary dispute, dating from 1472 and involving the subjects of Trikaten, contain references to wood-felling sites, meadows, fields and bee gardens within the wider district of Trikāta (LGU 1, 487). Documentary sources from across medieval Livonia often refer to fields, meadows, mills and rights related to pasturing, fishing, cutting of firewood, and beekeeping.

The picture of land-use from northern Livonia (Estonia) during the medieval period is marked in pollen sequences by contrasting patterns of vegetation change and land-use, characterised in some areas by increasing intensity in agricultural activity and in other areas by stability or even a decline in land-use. There are suggestions of relative stability and intensification in land-use across south-eastern and northern Estonia (Niinemets and Saarse 2009; Sillasoo et al 2009). However, short-term decreases in cereal pollen and open land are argued to reflect the impact of battle and plague, including at Parika Mire (central Estonia) c. 1200-1250 (Niinemets et al 2002), and a clear decline in arable and pastoral indicators at Lake Lasva during the mid-14 ${ }^{\text {th }}$ century ascribed to the impact of the Black Death (Niinemets and Saarse 2009). There is clearly a danger in linking historical events and palaeoecological data without a sufficiently robust chronology, and most pollen sequences across Livonia are rather ambiguous without clear evidence for the impact of plague or conflict. Very little is known about the Black Death in Livonia, but the late arrival and relatively sparse population density 
may have largely limited the impact to the key urban centres with more limited impact on more isolated rural landscapes.

\subsection{Cēsis castle environs}

The evidence from the hinterland pollen sequences contrasts with data from the moat at Cèsis where pollen suggests that the immediate environs of the castle are likely to have been largely cleared by the $14^{\text {th }}$ century when the castle underwent a major phase of expansion. Many of the cereal, weed and ruderal pollen taxa are present in the plant macrofossils record (Brown and Badura 2017; Banerjea and Badura 2019), including plants characteristic of disturbed soils (hemp nettle, pale persicaria, common chickweed), meadows (ragged robin, creeping buttercup, tormentil), segetal weeds (cornflower, black-bindweed, sheep's sorrel, annual knawel) and farinaceous plants (rye, wheat, oat and buckwheat) the latter group forming the basis of the diet of the castle inhabitants. The single seed of fig (Ficus carica) also provides evidence for long-distance trade and the high status of the castle.

However, interpretation of the data requires an understanding of the varied sources of the palaeoenvironmental remains. Cereal pollen in the moat likely derive from numerous sources, including grain stored in the outer bailey, a component of animal dung and fodder, as well as kitchen and latrine waste flushed into the moat. The majority of plant macrofossils recorded from the moat were most obviously washed in as waste material from the kitchen and latrines. Cereal pollen has been shown to be present in grain products even after baking (Greig 1982), also surviving in beer (Rösch 2005).

Many of the segetal weeds are likely to have been brought into the castle along with the grain. The high values of grass pollen may reflect the open ground within and surrounding the castle but may also have been contained within hay used as fodder or bedding, perhaps for horses stabled in the castle. The remains of food, grain products and animal fodder will have resulted in rotting food waste, along with human and animal faeces, that are likely to have attracted insects themselves transporting pollen from plants growing with the surrounding environment.

The pollen and archaeobotanical material from the moat clearly reflect the diet and socioeconomic status of the castle inhabitants but is also a reflection of the provisioning capacity and political power of the castle in the $14^{\text {th }}$ and $15^{\text {th }}$ centuries. Documentary sources from the $15^{\text {th }}$ century show that Cēsis was an important storehouse of cereals, with the grain 
stored in the castle accounting for almost a third of all stored grain in Livonia, a significant part of which was used to concentrate power with the Livonian Master. Moreover, the town and castle of Cēsis was situated on an important Hanseatic trade route. Documentary sources emphasise that during the fifteenth and sixteenth century, in addition to goods from Russia and the west, residents of Cēsis also sold their own goods including linen, hemp, flax, hops, leather, honey and beeswax (Kḷaviņš 2012), no doubt grown on farms in the surrounding landscape.

\subsection{Long-term continuity of pre-medieval land management practices}

One of the noticeable aspects of the palynological sequences is the relatively small quantities of microscopic charcoal, suggesting that fire formed a relatively minor aspect of land-management practices. However, in a recent paper, Jääts et al (2010) reviewed the historical evidence for the long-term maintenance of fire cultivation in Estonia up to the nineteenth century. They argue Estonia formed part of a wider zone of fire cultivation, including Latvia, Scandinavia and parts of northern Russia, where this form of land-use was both more prevalent than previously thought and persisted for far longer than in other parts of Europe. In addition to slash and burn and burn beating, the latter technique involving the burning of branches covered in soil, small plots of land were also cultivated in areas covered by young trees and bushes, termed bushlands. These bushlands are argued to have made up as much as $25 \%$ of all farmlands in southern Estonia by the nineteenth century (Meikar and Uri 2000), replacing earlier techniques of fire cultivation which were argued to have been more widespread across Livonia during the sixteenth and seventeenth centuries (Ligi 1963).

These forms of agricultural land-use therefore seem likely to have persisted in use during the medieval period alongside the development of more intensive cultivation within permanent fields. Fire cultivation is potentially rather difficult to identify in the palynological record from Latvia, limited to small clearings within woodland that will have severely constrained the wider dispersal of microscopic charcoal particles and cereal and herb pollen. Declines in alder and spruce pollen during the Iron Age have been linked with developments in agriculture, such as the use of iron implements, and an increasing requirement for more agricultural land as populations expanded (Saarse et al 2010). Clearance of spruce often followed the clearance of alder, a pattern that is visible to varying degrees in the pollen 
sequences presented here as well as from both Trikāta and Āraiši during the Iron Age and medieval period (Stivrins et al 2015).

Declines in alder are not necessarily linked to human activity but instead may be at least partially linked to disease and pathogen attack widely recorded in palynological data across Europe at the end of the first millennium AD (Latałowa et al 2019). The declines in spruce in several cases precede and are apparently unconnected to increases in human indicators. It seems likely however in these cases that spruce declines are reflecting land-use occurring within the wider landscape that is otherwise palynologically invisible, perhaps of the form discussed by Jääts et al (2010) and occurring largely within small forest clearings. The increase in cereal, field weed and ruderal pollen from the fourteenth century reflects intensification in crop cultivation, characterised in part by the expansion of permanent rotation field systems. This occurs against a backdrop of increased political stability, the growth of urban centres, the growing significance of the Hanseatic League and foreign trading networks, the establishment of serfdom and the development of the manorial system that created an increased demand for agricultural produce. The growing importance of cereals, particularly rye, is demonstrated not only by the pollen evidence but through documentary and archaeobotanical evidence for its growing significant as a consumable, tradable and taxable commodity (Sillasoo and Hiie 2007). It seems likely, however, that traditional forms of landuse continued in use, perhaps persisting in more rural areas further from the principal towns. Colonization occurred at a significantly lower rate within Livonia and the continuation of preconquest practices is reflected not just in the use by indigenous communities of Iron Age farming implements on medieval sites (e.g. Mugurēvicš 1990, 2008), but also the survival of traditional burial customs and continued use of sacred natural places (Laul and Valk 2007; Valk 2009); the palynological evidence contributes to this picture of change and continuity.

\subsection{Comparing Livonia and Prussia}

In both cases the conquest of Livonia and Prussia was facilitated by fragmented tribal polities and the expansionist agendas of the conquering powers. However, in Prussia, a larger proportion of the indigenous population was killed during the crusades, with comparatively small numbers of casualties in Livonia where there was a greater survival of indigenous power structures. Moreover, the survival of indigenous populations can be linked with levels of 
colonization which were far greater in Prussia than in Livonia where colonists were largely restricted to the towns and castles (Pluskowski 2019a).

The population of Prussia by the beginning of the $14^{\text {th }}$ century has been estimated at 220,000 (Biskup 2002), concentrated most densely around the towns and castles in western Prussia, focused around the Kulmerland and Lower Vistula Basin extending from Torun in the south to Gdańsk in the north and Elblag in the east. Environmental impact was therefore most pronounced in those areas most intensively colonised. In western Prussia the arrival of the Teutonic Order and German colonists is preceded in many areas by increasing deforestation and agricultural intensification associated with Slavic colonization from the $7^{\text {th }} / 8^{\text {th }}$ centuries and the expansion of the Polish state from the mid-10 ${ }^{\text {th }}$ century (Brown et al 2015, 2019; Lamentowicz et al 2007, 2008; Latałowa et al 2009; Noryśkiewicz 2004a, b, 2005, 2013; Pędziszewska and Latałowa 2016; Święta-Musznicka et al 2013). Territories in the east, including much of the Great Masurian Lakelands, saw more limited colonization until the mid$15^{\text {th }}$ century following the end of the Thirteen Years War (1466) where there is a variable pattern of both continuity and discontinuity in settlement and land-use before and after the crusades. The palynological evidence for variable land-use reflects the complex tribal politics of the Iron Age, the variable impact of the crusades and the subsequent development of the landscape as an unstable frontier zone with Lithuania over the mid-13 ${ }^{\text {th }}$ to mid- $15^{\text {th }}$ centuries. (Wacnik et al 2014; Gałka et al 2014; Szal et al 2014, 2016; Brown and Pluskowski 2014).

Parts of Livonia likewise developed into unstable frontier zones, particularly to the south bordering the Grand Duchy of Lithuania; a pattern mirrored on the opposite side of the border in north-western Lithuania (Curonia and Samogitia) where several pollen sequences show evidence for declining human activity and woodland regeneration Stančikaitè et al 2004, 2006). This is most obvious from Impiltis, an Iron Age hillfort on the Curonian coast where the reduction in human activity coincides with the destruction of the hillfort by the Teutonic Order in 1263 (Stančikaitè et al 2009); what was an actively settled land in the Iron Age and became a frontier zone in the medieval period.

\section{Conclusion}

The variability in land-use recorded in pollen sequences across Livonia and Prussia reflect a complex interplay of factors including; the nature of pre-conquest tribal politics; the degree 
of survival of indigenous populations and indigenous land-use traditions; the stability of the conquered territories and density and intensity of colonization, and the quality and productivity of the land and requirements for specific land-use practices.

Population densities were lower in medieval Livonia compared to those most densely settled areas in western Prussia but saw a greater survival of indigenous populations and power structures. Colonization was initially limited to the towns and castles, and around Cēsis pollen sequences suggest a high degree of continuity in vegetation and land-use in the century following the crusades. The intensification in agriculture in the $14^{\text {th }}$ century, a century after the crusades, occurs against a backdrop of increased political stability, the growth of urban centres, the growing influence of the Hanseactic League and foreign trading networks, the establishment of serfdom and the development of the manorial system that created an increased demand for agricultural produce.

Despite the low intensity of human activity recorded in the pollen sequences, indigenous land-use practices appear likely to have persisted throughout the medieval period alongside the introduction of new forms of land-use, including permanent rotational field systems. However, it seems plausible to suggest that the landscape to the north, north-east and northwest of Cēsis retains much of its natural character in terms of vegetation. Here the sandy soils are of marginal to poor agricultural potential and retain a heavy woodland cover, compared to the boulder clay soils located to the south-east of Cēsis where palaeoenvironmental evidence suggests more of a mosaic vegetation landscape since the late Iron Age.

Although Cēsis castle became a major power centre in Livonia from the $14^{\text {th }}$ century, and particularly in the $15^{\text {th }}$ century, its ability to concentrate power and resources from across large parts of Livonia was more significant than its impact on the surrounding environment; Cēsis was a major power centre located in a marginal landscape.

\section{Acknowledgements}

The research leading to this publication has received funding from the European Union's 940 Seventh Framework Programme (FP7/2007-2013) under grant agreement No.263735. The authors thank Gundars Kalnins for his invaluable guidance and assistance during the course of work at Cēsis, and for helping selecting sites for coring, and to Rowena Banerjea, Kevin Williams, Rob Batchelor and Jenny Austin during fieldwork. The authors thank the reviewers for their helpful comments on the manuscript. 


\section{References}

Andersen S. T. 1978. "Identification of wild grasses and cereal pollen." Danmarks Geologiske Undersøgelse, Årbog 1978: 69-92.

Apals, J. 2002. “Āraiši lake fortress in Latvia." Viking Heritage Magazine 4: 24-25.

Apals, J. 2012. Āraišu ezerpils: rakstu izlase un draugu atmiṇas, Rīga: LU Latvijas vēstures institūts.

Apala, Z, and Apals, J. 2014. "The Vendic hillfort on Riekstu Kalns in Cēsis." In Strongholds and Power Centres East of the Baltic Sea in the $11^{\text {th }}$ and $13^{\text {th }}$ centuries, edited by $\mathrm{H}$ Valk, 115-138. Tartu, Institute of History and Archaeology at the University of Tartu, Department of Archaeology at the Institute of History of Tallinn University.

Banerjea and Badura 2019 "Settlement Life in Livonia and the Impact on the Hinterlands: The Geoarchaeological and Archaeobotanical Evidence." In Environment, Colonization and the Crusader States in Medieval Prussia and Livonia: Terra Sacra 1, edited by A. Pluskowski, 175-206. Turnhout: Brepols

Biskup, M. 2002. “Etniczno-demograficzne przemiany Prus Krzyżackich w rozwoju osadnictwa w średniowieczu." In Opera Minora: Studia z dziejów zakonu Krzyżackiego, M. Biskup (collected essays), Toruń: Towarzystwo Naukowe w Toruniu, 129-150.

Blaauw, M., van der Plicht, J., and van Geen, B. 2004. "Radiocarbon dating of bulk peat samples from raised bogs: non-existene of a previously reported 'reservoir effect'?" Quaternary Science Reviews 23: 1537-1542.

Blaauw, M., and Christen, A. 2011. "Flexible palaeoclimate age-depth models using an auto-regressive gamma process." Bayesian Analysis 6: 457-474.

Bronk-Ramsey, C. 2009. OxCal Calibration Programme Version v4.10. University of Oxford: Radiocarbon Accelerator Unit.

Brown, A. D. 2019. "Vegetation change in Livonia: the palynological data." In Environment, Colonization and the Crusader States in Medieval Prussia and Livonia: Terra Sacra 1, edited by A. Pluskowski, 105-136. Turnhout: Brepols

Brown, A. D., and Badura, M. 2017. "Plant macrofossil and pollen analysis from the moat and outer bailey at Cēsis castle: indicators of local environment and plant use." In Cēsu pils raksti, vol. 1, edited by Gundars Kalnins. Cēsu pils saglabāšanas. 
Brown, A. D., and Pluskowski, A. G., 2014. "Medieval landscape transformation in the southeastern and eastern Baltic: palaeoenvironmental perspectives on the colonization of frontier landscapes." Archaeologia Baltica 20: 24-46.

Brown, A. D., Banerjea, R. Y., Wynne, A-D., Stivrins, N., Jarzebowski, M., Shillito, L-M. and Pluskowski, A. G. 2015. "The ecological impact of conquest and colonization on a medieval frontier landscape: combined palynological and geochemical analysis of lake sediments from Radzyń Chełmiński, northern Poland." Geoarchaeology 30(6): 511-527.

Brown, A .D., Poska, A., Pluskowski, A. G. 2019. "The environmental impact of cultural change: palynological and quantitative land-cover reconstructions for the last two millennia in northern Poland." Quaternary International 522: 38-54.

Christiansen, E. 1997. The Northern Crusades. Penguin, London.

Cushing E. J. 1967. “Evidence for differential pollen preservation in late Quaternary sediments in Minnesota." Review of Palaeobotany and Palynology 4: 87-101.

Draveniece, A. 2009. "Detecting changes in winter seasons in Latvia: the role of arctic air masses." Boreal Environment Research 6095, 89-99.

Forest Europe, UNECE, and FAO, 2011. "State of Europe's Forests 2011. Status and Trends in Sustainable Forest Management in Europe." Oslo: Forest Europe.

Gałka, M., Tobolski, K., Zawisza, E., and Goslar, T. 2014. “Postglacial history of vegetation, human activity and lake-level changes at Jezioro Linówek in northeast Poland, based on multi-proxy data." Vegetation History and Archaeobotany 23: 123-152.

Greig, J. 1982. "The interpretation of pollen spectra from urban archaeological deposits." In Environment Archaeology in the Urban Context, edited by A. R. Hall and H. K. Kenward, York: CBA Research Report 43.

Grimm, E.C. 2011. Tilia 1.7.16 Software. Springfield: Illinois State Museum, Research and Collection Center.

Heikkilä, M., and Seppä, H. 2010. “Holocene climate dynamics in Latvia, eastern Baltic region: a pollen-based summer temperature reconstruction and regional comparison." Boreas 39: 705-719.

Jāāts, L., Kihno, K., Tomson, P., and Konsa, M. 2010. "Tracing fire cultivation in Estonia." Forestry Studies 53: 53-65. 
Kalninga, L., Stivrins, N., Kuske, E., Ozola, I., Rujate, A., Zeimule, S., Grudzinska, I., and Ratnice, V. 2015. "Peat stratigraphy and changes in peat formation during the Holocene." Quaternary International 383: 186-195.

Kangur, M., Koff, T., Punning, J-M., Vainu, M. and Vandel, E. 2009. "Lithology and biostratigraphy of the Holocene succession of Lake Kuži, Vidzeme Heights (Central Latvia)." Geological Quarterly 53: 199-208.

Kihno, K., and Valk, H. 1999. "Archaeological and palynological investigations at Ala-Pika, south-eastern Estonia." PACT 57: 221-237.

Kušḳe, E., Silamiḳele, I., Kalniṇa, L., and Kḷaviṇš, M. 2010. “Peat formation conditions and peat properties: a study of two ombrotrophic bogs." In Mires and Peat, edited by M. Klavins, 56-70. Rīga: University of Latvia Press.

Lamentowicz, M., Tobolski, K., and Mitchell, E. A. D. 2007. "Palaeoecological evidence for anthropogenic acidification of a kettle-hole peatland in northern Poland." The Holocene 17: 1185-1196.

Lamentowicz, M., Cedro, A., Gałka, M., Goslar, T., Miotk-Szpiganowicz, G., Mitchell, E. A. D., and Pawlyta, J. 2008. "Last millennium palaeoenvironmental changes from a Baltic bog (Poland) inferred from stable isotopes, pollen, plant macrofossils and testate amoeba." Palaeogeography, Palaeoclimatology, Palaeoecology 265: 93-106.

Latałowa, M., Święta-Musznicka, J., and Pędziszewska, A. 2009. “Żródła paleobotaniczne do rekonstrukcji wczesnych etapórozwoju Gdańska." In Środowisko-Człowiek-Cywilizacja, 2, edited by. L. Domańska, P. Kittel, and J. Forysik, 175-185. Poznań: Bogucki Wydawnictwo Naukowe.

Latałowa, M., Święta-Musznicka, J., Słowiński, M., Pędziszewska, A., Noryśkiewicz, A.M., Zimny, M., Obremska, M., Ott, F., Stivrins, N., Pasanen, L., Ilvonen, L., Holmström, L., Seppä, H. 2019. "Abrupt Alnus population decline at the end of the first millennium CE in Europe The event ecology, possible cause and implications." The Holocene 29, 1335-1349. Laul, S., and Valk, H. 2007. Siksälä: A Community at the Frontiers: Iron Age and Medieval, Tartu: University of Tartu.

Ligi, P. 1992. "The prehistory of Saaremaa." PACT 37: 163-173.

Ligi, H. 1963. Põllumajanduslik maakasutus Eestis XVI-XVII sajandil. Tallinn: Eesti NSV Teaduste Akadeemia Ajaloo Instituut. 
Meadows, J., and Zunde, M. 2014. "A lake fortress, a floating chronology and an atmospheric anomaly: the surprising results of a radiocarbon wiggle-match from Āraiši, Latvi." Geochronometria 41: 223-233.

Meikar, T., and Uri, V. 2000. "Managing the bushlands in Estonia." Akadeemilise Metsaseltsi Toimetised 11: 103-120.

Moore P. D., Webb, J. A., and Collinson, M. E. 1991. Pollen Analysis, Oxford: Blackwell (second edition).

Mugurēvičs, E. 13th to 16th centuries." In From the Baltic to the Black Sea, edited by. D. Austin and L. Alcock, 168-178. London: Routledge.

Mugurēvicš, Ĕ., 2008. Viduslaiku ciems un pils Salaspils novadā, Rīga: Latvijas vēstures institūta apgāds.

Niinemets, E., and Saarse, L. 2009. "Holocene vegetation history and land-use dynamics of south-eastern Estonia." Quaternary International 207: 104-116.

Niinemets, E., Saarse, L., and Poska, A. 2002. "Vegetation history and human impact in the Parika area, central Estonia." Proceedings of the Estonian Academy of Science Geology 51: 241-258.

Nilsson, M., Klarqvist, M., Bohlin, E., and Possnert, G. 2001. "Variation in 14C age of macrofossils and different fractions of minute peat samples dated by AMS." The Holocene 11, 579-586.

Noryśkiewicz, A. M. 2004a. “Analiza pyłkowa osadów biogenicznych terasy zalewowej Wisły w profile Chełmno/Rybaki." In Wczesnośredniowieczny zespół osadniczy Kałdusie. Studia przyrodniczo-archeologiczne, edited by W, Chudziak, 143-150. Toruń: UMK. Noryśkiewicz A, M. 2004b. “Przemiany w szacie roślinnej okolic Uścia w okresie ostatnich dwóch tysięcy lat." In Wczesnośredniowieczny zespół osadniczy Kałdusie. Studia przyrodniczo-archeologiczne, edited by W, Chudziak, 151-163. Toruń: UMK. Noryśkiewicz, A. M. 2005. "Preliminary results of study on vegetation history in the Linje mire region using pollen analysis." Monographiae Botanicae 94: 118-133.

Noryśkiewicz, A. M. 2013. Historia roślinności i osadnictwa ziemi Chełminskiej w późnym Holocenie. Studium palinologiczne. Toruń: Wydawnictwo Naukowe Uniwersytetu Mikolaja Kopernika. 
Ozola, I. 2013. Holocēna organogēnie nogulumi un to uzkrāšanās apstāklu izmainas purvos ziemel Vidzemē. Unpublished doctoral thesis, University of Rīga.

Pakalne, M., and Kalnina, L. 2005. "Mire ecosystems in Latvia." In From Siberia to Tierra del Fuego, edited by G. M. Steiner, 147-174. Linz: Biologiezentrum der Ober Biologiezentrum der Oberösterreichischen Landesmuseen.

Pędziszewska, A., and Latałowa, M. 2015 "Stand-scale reconstruction of late Holocene forest succession on the Gdańsk Upland (N. Poland) based on integrated palynological and macrofossil data from paired sites." Vegetation History and Archaeobotany 25: 239-254 Pluskowski, A. G. (ed.) 2019a Environment, Colonization and the Crusader States in Medieval Prussia and Livonia: Terra Sacra 1. Turnhout: Brepols.

Pluskowski, A. G. (ed.) 2019b. Ecologies of Crusading, Colonization, and Religious Conversion in the Medieval Baltic: Terra Sacra 2. Turnhout: Brepols.

Poska, A., Seep, E., Veski, S., and Koppel, K. 2008. “Using quantitative pollen-based estimations and a spatial CA_Markov model to reconstruct the development of cultural landscape at Rõuge, South Estonia." Vegetation History and Archaeobotany 17: 527-541. Poska, A., Saarse, L., Koppel, K., Nielsen, A. B., Avel, E., Vassiljev, J., and Väli, V. 2014. “The Verijärv area, South Estonia over the last millennium: a high-resolution quantitative landcover reconstruction based on pollen and historical data." Review of Palaeobotany and Palynology 207: 5-17.

Punning J-M., Liiva A., and Ilves E. 1968. "Tartu radiocarbon dates III." Radiocarbon 10: 379383.

Reimer, P.J., Bard, E., Bayliss, A., Beck, J.W., Blackwell, P.G., Bronk Ramsey, C., Buck, C.E., Cheng, H., $\quad$ Edwards, R.L., Friedrich, M., Grootes, P.M., Guilderson, T.P., Haflidason, H., Hajdas, I., Hatté, C., Heaton, T.J., Hoffmann, D.L., Hogg, A.G., Hughen, K.A., Kaiser, K.F., Kromer, B., Manning, S.W., Niu, M., Reimer, R.W., Richards, D.A., Scott, E.M., Southon, J.R., Staff, R.A., Turney, C.S.M., \& van der Plicht, J. 2013. "Intcal13 and marine13 radiocarbon age calibration curves 0-50,000 years cal BP." Radiocarbon 55: 1869-1887.

Rösch, M. 2005. "Pollen analysis of the contents of excavated vesses: direct archaeobotanical evidence of beverages." Vegetation History and Archaeobotany 14: 179188. 
Saarse, L., Niinemets, E., Poska, A., and Veski, S. 2010. "Is there a relationship between crop farming and the Alnus decline in the eastern Baltic region?" Vegetation History and Archaeobotany 19: 17-28.

Segerström, U. 1990. The natural Holocene vegetation development and the introduction of agriculture in northern Norrland, Sweden: studies of soil, peat and especially varved lake sediments. Unpublished doctoral dissertation, University of Umeå.

Segerström, U., and Emanuelsson, M. 2002. "Extensive forest grazing and hay-making on mires - vegetation changes in south-central Sweden due to land use since medieval times." Vegetation History and Archaeobotany 11: 181-190.

Sillasoo, Ü. and Hiie, S. 2007. "An archaeobotanical approach to investigating food of the Hanseatic period in Estonia." In Medieval food traditions in Northern Europe, edited by S. Karg, 73-96. Copenhagen: National Museum of Denmark.

Sillasoo, Ü., Poska, A., Seppā, H., Blaauw, M., and Chambers, F. M. 2009. “Linking past cultural developments to palaeoenvironmental changes in Estonia." Vegetation History and Archaeobotany 18: 315-327.

Šnē, A. 2005. "Archaeological evidence of social relations and power in the late prehistoric societies of the Livs." Suomalaisen tiedeakatemian toimituksia. Sarja Humaniora 336: 169185.

Šnē, A. 2006. "The economy and social power in the late prehistoric chiefdoms in eastern Lativa." Archaeologia Baltica 6: 68-78.

Stančikaitè, M., Kisielienè, D., and Strimaitienè, A. 2004. "Vegetation response to the climatic and human impact changes during the Late Glacial and Holocene: case study of the marginal area of Baltija Upland, NE Lithuania." Baltica 17: 17-33.

Stančikaitè, M., Baltrūnas, V., Šinkūnas, P., Kisielienė, D., and OstrauskaS, T. 2006. “Human response to the Holocene environmental changes in the Biržulis Lake region, NW Lithuania" Quaternary International 150: 113-129.

Stančikaitè, M., Šinkūnas, P., Risberg, J, Šeirienė, V., Blažauskas, N., Jarockis, R., Karlsson, S., and Miller, U. 2009. "Human activity and the environment during the Late Iron Age and Middle Ages at the Impiltis archaeological site, NW Lithuania." Quaternary International 20: 74-90.

Stančikaitè, M., Bliujiene, A., Kisielienė, D., Mažeika, J., Taraškevičius, R., Messal, S., Szwarczewski, P., Kusiak, J., and Stakènienè, R. 2013. “Population history and 
palaeoenvironment in the Skomantai archaeological site, West Lithuania: two thousand years." Quaternary International 308-309: 190-204.

Stivrins, N., Brown, A., Reitalu, T., Veski, S., Heinsalu, A., Banerjea, R. Y., and Elmi, K. 2015. "Landscape change in central Latvia since the Iron Age: multiproxy analysis of the vegetation impact of conflict, colonization and economic expansion during the last 2,000 years." Vegetation History and Archaeobotany 24: 377-391.

Stivrins, N., Brown, A.D., Reitalu, T., Ratniece, V., Austin, J.E., Liiv, M., Cerina, A., and Veski, S. 2016. "Palaeoenvironmental evidence for the impact of the crusades on the local and regional environment in northern Latvia: terrestrial evidence." The Holocene 26: 61-69. Stivrins, N., Veski, S., and Reitalu, T. 2019. "Palynological evidence of Crusader and subsequent impact on the Livonian landscape." Ecologies of Crusading, Colonization, and Religious Conversion in the Medieval Baltic: Terra Sacra 2, 147-152. Turnhout: Brepols. Stuiver, M. And Polach, H.A. 1977. "Reporting of 14C data. " Radiocarbon 19, 355-356. Święta-Musznicka, J., Latałowa, M., Badura, M., and Gołembnik, A., 2013. “Combined pollen and macrofossil data as a source of reconstructing mosaic patterns of the early medieval urban habitats - a case study from Gdańsk, N. Poland." Journal of Archaeological Science 40: 637-638.

Szal, M., Kupryjanowicz, M., Wyczółkowski M., and Tylmann, W. 2014. "The Iron Age in the Mrągowo Lake District, Masuria, NE Poland: the Salęt settlement microregion as an example of a long-lasting human impact on vegetation." Vegetation History and Archaeobotany 23: 419-437.

Szal, M., Kupryjanowicz, M., Tylmann, W and Piotrowska, N. 2016. "Was it 'terra desolata'? Conquering and colonizing the medieval Prussian wilderness in the context of climate change." The Holocene 27: 465-480.

Urban, W., 2003. The Teutonic Knights: A Military History. Greenhill Books, London. Valrianta, M., Oinonen, M., Seppa, H., Korkonen, S., Juutinen, S., and Tuittila, E-S. 2014. "Unexpected problems in AMS 14C dating of fen peat." Radiocarbon 56, 95-108. Valk, H. 2009. "Sacred and natural places of Estonia: regional aspects." Folklore 42, 45-66. Vaughan, J., and Geissler, C. 1997. The New Oxford Book of Food Plants, Oxford: Oxford University Press. 
Veski, S., Koppel, K. and Poska, A. 2005. "Integrated palaeoecological and historical data in the service of fine resolution land use and ecological change assessment during the last 1000 years in Rōuge, southern Estonia." Journal of Biogeography 32, 1473-1488.

Wacnik, A., Kupryjanowicz, M., Mueller-Bieniek, Karczewski, M., and Cywa K. 2014. "The environmental and cultural contexts of the late Iron Age and medieval settlement in the Mazurian Lake District, NE Poland: combined palaeoebotanical and archaeological data." Vegetation History and Archaeobotany 23: 419-437.

Zelčs, V., and Markots, A. 2004. "Deglaciation history of Latvia." In Quaternary Glaciations: Extent and Chronology of Glaciations, edited by. J. Ehlers, L. Gibbard, and P. Hughes, 225243. Amsterdam: Elsevier. 


\section{Figure captions}

Fig. 1 Location map showing A) part of the Baltic in detail: B) the Teutonic Order's territories comprising Prussia and Livonia and showing those pollen sequences mentioned in text, and C) Location of pollen studies. Pollen sequences mentioned in text: 1 - Āraiši (Stivrins et al 2015), 2 - Eipurs mire (Kušḳe et al 2010), 3 - Dzelve-Kronis mire (Kušḳe et al 2010), 4 - Lake Ķuži (Kangur et al 2009), 5 - Bazi Mire (Pakalne and Kalniṇa 2005), 6 - Lake Kurjanovas (Heikkilä and Seppä 2010), 7 -Rożu Bog (Kušḳe et al 2011; Kalniṇa et al. 2014), 8 - Zilais Mire (Kalniņa et al 2014), 9 - Trikata (Stivrins et al 2016), 10 - Zosna peatland (Ozola 2013), 11 Parika mire (Niinemets et al 2002),

Fig. 2 Age-depth models, Blusu mire, Nineris Mire, Blanku mire and Rāmuḷi. Note that the agedepth model from Rāmuḷi includes an addition radiocarbon date at $80 \mathrm{~cm}$ whilst pollen was only analysed to $50 \mathrm{~cm}$ core depth.

Fig. 3 Blusu mire, selected taxa percentage pollen diagram. Black curve = percentage of taxon, grey curve $=$ values exaggerated $\mathrm{x} 10$.

Fig. 4 Nineris mire, selected taxa percentage pollen diagram. Black curve $=$ percentage of taxon, grey curve $=$ values exaggerated $\times 10$.

Fig. 6 Blanku mire, selected taxa percentage pollen diagram. Black curve = percentage of taxon, grey curve $=$ values exaggerated $\times 10$.

Fig. 6 Rāmuḷi, selected taxa percentage pollen diagram. Black curve = percentage of taxon, grey curve $=$ values exaggerated $\times 10$.

Fig. 7 Cēsis moat, selected taxa percentage pollen diagram. Black curve = percentage of taxon, grey curve $=$ values exaggerated $\times 10$. 